\section{Responses of Lettuce Cultivars to Insect Pests in Southern Florida}

\author{
Huangjun $\mathrm{Lu}^{1,3}$, Alan L. Wright ${ }^{1}$, and David Sui ${ }^{2}$
}

AdDitionAl INDEX wORDs. host plant resistance, banded cucumber beetle, serpentine leafminer, aphids

Summary. Banded cucumber beetle [BCB (Diabrotica balteata)], serpentine leafminer [SL (Liviomyza trifolii)], and aphids (Homoptera: Aphididae) are among the major insect pests that cause significant economic damage to lettuce (Lactuca sativa) in southern Florida. Four romaine cultivars and three iceberg cultivars, currently used in Florida's lettuce production, were evaluated from Oct. 2010 to Jan. 2011 in separate field experiments for their responses to insect infestation. Lettuce cultivars differed significantly in their responses to infestations of $\mathrm{BCB}$ and aphids. Cultivar 70096 had the lowest percent (3.7\%) of BCB feeding damage among the romaine cultivars. Romaine cultivar Manatee also had significantly lower BCB feeding damage (12.1\%) than the susceptible cultivars Okeechobee (19.8\%) and Terrapin (19.1\%). The lowest level of infestation of aphids was observed on 'Manatee', followed by '70096', whereas 'Okeechobee' and 'Terrapin' had severe infestation of aphids. The iceberg cultivars were similar to one another in their responses to BCB and SL but not in their response to aphid infestation. Yield was decreased from 3\% to $37 \%$ for six of the seven cultivars grown under the adverse environmental conditions of insect infestations and cold weather in Dec. 2010, but the yield of '70096' did not decline. The cultivars identified as resistant to insects can play an important role in integrated pest management (IPM), which may decrease pesticide application, reduce production costs, and protect the environment.

L ettuce is the most popular ingredient of salads or salad mixes consumed in the United States. The U.S. growers planted $\approx 278,900$ acres of lettuce and produced 90 million cwt of lettuce ( 53 million cwt of head lettuce, 26 million cwt of romaine lettuce, and 11 million cwt of leaf lettuce) in 2009 (U.S. Department of Agriculture, 2011). Lettuce production practices in Florida are unique as the growing season begins in early October and harvest finishes in the mid-May. The subtropical climate of Florida facilitates lettuce production from fall through spring, but the warm and moist conditions are also favorable for insect proliferation and damage.

Banded cucumber beetle, serpentine leafminer, and aphids are among the major pests causing significant economic damage to lettuce in Florida. $\mathrm{BCB}$ is a phagous insect with a host

We thank Dr. Yigang Luo, Dr. Gregg Nuessly, and Ms. Amanda Carroll for technical assistance and Mr. David Basore for providing lettuce seeds for the present study.

${ }^{1}$ Everglades Research and Education Center, University of Florida/Institute of Food and Agricultural Sciences, Belle Glade, FL 33430

${ }^{2}$ Commercial Vegetable \& Tropical Fruit, University of Florida/Institute of Food and Agricultural Sciences, Palm Beach County Cooperative Extension, West Palm Beach, FL 33415

${ }^{3}$ Corresponding author. E-mail hjlu@ufl.edu. spectrum of more than 50 plant species in 23 families (Saba, 1970). Economic losses caused by BCB have been reported in other crops, including cucumber [Cucumis sativus (Da Costa and Jones, 1971)], common bean [Phaseolus vulagaris (Cardona et al., 1982)], sweetpotato [Ipomoea batatas (Schalk et al., 1986)], and soybean [Glycine max (Layton et al., 1987)]. Foliar feeding on lettuce by BCB adults leads to decreased photosynthetic area, increased vulnerability to diseases, and reduced market grade (Nuessly and Nagata, 1993). SL is also polyphagous and attacks lettuce and other vegetable crops (Drees and Jackman, 1999). Plant leaves are damaged as SL larvae tunnel through the inner leaf tissue producing so-called whitish "mines" that reduce the photosynthetic area, and lettuce becomes unmarketable if infestation is severe (Nuessly and Nagata, 1994). Several species of aphids affect lettuce, including green peach aphid (Myzus percicae), potato aphid (Macrosiphum euphorbiae), the aphid Uroleucon pseudambrosiae, and lettuce aphid (Nasonovia ribisnigri). The lettuce aphid is a problem worldwide and has recently become problematic in the western United States and Canada (Liu and McCreight, 2006; McCreight, 2008 ), but the first three species of aphids are most economically damaging in Florida (Nuessly and Webb, 2010). Although heavy aphid pressure can stunt plants, the major problem caused by aphids is head contamination, which makes lettuce unmarketable. In addition, aphids are the vectors for transmission of lettuce mosaic virus and bidens mottle virus (Nuessly and Webb, 2010).

Control of BCB, SL, and aphids in lettuce production is historically dependent on application of pesticides. However, there are disadvantages associated with pesticide uses for insect control, including increased production costs, adverse environmental and ecological effects, and development of pesticide resistance in insects. One alternative for effective control of insects is the use of host plant resistance, which is an environmentally friendly method compatible with other approaches used in IPM (Smith, 1989).

Host plant resistance in lettuce to BCB and SL has been identified, as Nuessly and Nagata (1994) reported that 'Valmaine', a romaine lettuce cultivar, had a high level of resistance to SL. This cultivar was later found to be resistant to BCB (Huang et al., 2002; Sethi et al., 2008) and two lepidopterans, Trichoplusia ni and Spodoptera exigua (Sethi et al., 2006). 'Valmaine' is an obsolete cultivar that was used in lettuce production in 1970s and then used as a parent for crosses for development of romaine cultivars in the University of Florida (UF) lettuce

\begin{tabular}{llll}
\hline $\begin{array}{l}\text { Units } \\
\text { To convert U.S. to SI, } \\
\text { multiply by }\end{array}$ & U.S. unit & SI unit & $\begin{array}{l}\text { To convert SI to U.S., } \\
\text { multiply by }\end{array}$ \\
\hline 0.4047 & $\mathrm{acre}(\mathrm{s})$ & $\mathrm{ha}$ & 2.4711 \\
45.3592 & $\mathrm{cwt}$ & $\mathrm{kg}$ & 0.0220 \\
0.3048 & $\mathrm{ft}$ & $\mathrm{m}$ & 3.2808 \\
2.54 & inch $(\mathrm{es})$ & $\mathrm{cm}$ & 0.3937 \\
0.4536 & $\mathrm{lb}$ & $\mathrm{kg}$ & 2.2046 \\
1.1209 & $\mathrm{lb} / \mathrm{acre}$ & $\mathrm{kg} \cdot \mathrm{ha}^{-1}$ & 0.8922 \\
70.0532 & $\mathrm{oz} / \mathrm{acre}$ & $\mathrm{g} \cdot \mathrm{ha}^{-1}$ & 0.0143 \\
$\left({ }^{\circ} \mathrm{F}-32\right) \div 1.8$ & ${ }^{\circ} \mathrm{F}$ & ${ }^{\circ} \mathrm{C}$ & $\left(1.8 \times{ }^{\circ} \mathrm{C}\right)+32$ \\
& & &
\end{tabular}


breeding program (Guzman, 1986; Guzman and Zitter, 1983). The cultivars Short Guzmaine, Tall Guzmaine, Floricos 83, and Floriglade released in the 1980s (Guzman, 1986; Guzman and Zitter, 1983) contain 'Valmaine' in their pedigrees but have little SL resistance ('Short Guzmaine') or no resistance to either SL or $\mathrm{BCB}$, indicating that the high level of resistance in 'Valmaine' was not incorporated into these cultivars. Sources of resistance in lettuce to aphids were also documented (Reinink and Dieleman, 1989; Reinink et al., 1989). Arend et al. (1999) reported development of an aphid-resistant butterhead lettuce 'Dynamite'.

Responses of lettuce to $\mathrm{BCB}$ or SL were generally assessed under the controlled laboratory or greenhouse environment (Huang et al., 2002; Nuessly and Nagata, 1994). This approach can accurately distinguish resistant cultivars/lines from susceptible ones and determine if resistance is due to antibiosis or antixenosis. However, only a limited number of lettuce lines are evaluated and one insect species is studied at a time, which can hinder quick identification of resistance sources from a large collection of germplasm lines. Field test with natural insect infestation has been used in other crops such as maize (Butrón et al., 1998) and wheat (Sherman et al., 2010) but not in lettuce for evaluation of responses to BCB or SL. The established technology for studying reaction of lettuce to aphid infestation includes counting aphids (Palumbo et al., 2000; Reinink and Dieleman, 1989). The process of counting aphids is tedious and time consuming, and especially when a highly dense population of aphids develops on plants rendering it very difficult to count the individual aphids.

Cultivars that are currently being used in Florida's lettuce production were developed by the UF breeding program or introduced from other U.S. states. Information is limited on responses of these cultivars to $\mathrm{BCB}, \mathrm{SL}$, and aphids. It is desirable to investigate their performance in fields under attack from insect pests and to understand if any of the cultivars have resistance that can be incorporated into IPM tactics for insect control. Objectives of this study were to: 1 ) investigate population dynamics of BCB, SL, and aphids on lettuce; 2) evaluate responses of the cultivars to infestation of the insects under field conditions; and
3) identify resistance in cultivars that are useful as a component in IPM.

\section{Materials and methods}

Plant material. Four romaine cultivars (Okeechobee, Manatee, Terrapin, and 70096) and three iceberg cultivars (Gator, Raleigh, and 8074) were evaluated for responses to $\mathrm{BCB}, \mathrm{SL}$, and aphids infestations in field experiments. All but '70096' are current cultivars Florida growers use in lettuce production.

Field experiments. Two separate sets of experiments, one for romaine and one for iceberg cultivars, were carried out using a randomized complete block design. Each set of the experiments with four replications in each experiment were planted at two sites (referred as site one and two) in Belle Glade, FL. Planting dates were 22 Oct. 2010 at site one and 26 Oct. 2010 at site two. The beds were prepared $2 \mathrm{ft}$ wide with $\mathrm{l}$ - $\mathrm{ft}$ furrows to separate the adjacent beds. Plots consisted of two rows per cultivar and were $20 \mathrm{ft}$ long, with plant spacings at $\mathrm{l} \mathrm{ft}$ within row and $1.5 \mathrm{ft}$ between rows on the same bed. The soil at both sites was Dania muck (euic, hyperthermic shallow Lithic Haplosaprists). Plots were fertilized at planting with $50 \mathrm{lb} /$ acre nitrogen from urea, $87 \mathrm{lb} /$ acre phosphorus from triple superphosphate, and $166 \mathrm{lb} /$ acre potassium from potash. Imazethapyr at $0.45 \mathrm{oz} / \mathrm{acre}$ (Pursuit; BASF Corp., Research Triangle Park, NC) was applied to control weeds 1 week after lettuce emergence. Thereafter, weeds were controlled by manual hoeing to avoid possible compounding effects of herbicides on insects. To determine yield potential, the same cultivars were also planted on 7 Oct. in the nearby fields where the insects were controlled by application of pesticides. Cryomazine at $1.9 \mathrm{oz} /$ acre a.i. (Triguard; Syngenta, Wilmington, $\mathrm{DE})$ and $0.45 \mathrm{lb} /$ acre a.i. methomyl (Lannate; DuPont, Wilmington, DE) were applied for two times to control $\mathrm{SL}$ and BCB, respectively. Two applications of pymetrozine at $1.4 \mathrm{oz} /$ acre a.i. (Fulfill, Syngenta) were used to control aphids. The two sites were 5 miles away from each other.

Daily scouting for the presence of insects on lettuce started $\approx 2$ weeks after emergence. To understand population densities of BCB and SL populations in the field, $\mathrm{BCB}$ feeding incidents were recorded on each of
10 'Okeechobee' plants and SL mines were counted from each of 10 'Raleigh' plants every week starting on 18 Nov. at site one. To compare cultivars for their responses to infestations of $\mathrm{BCB}$ or SL, a percentage rating scale [ (damaged leaves/total leaves) $\times 100 \%]$ was assigned to each of 10 plants in each plot of the experiments at both sites on 16 Dec.

Readings of cultivar response to aphid infestation were taken from 10 plants in each plot at both sites on 20 Jan. 2011 as aphid population density peaked. Because potato aphid was the predominant species in the lettuce growing season and this species has a behavior of forming high dense colonies making it very difficult to count individual aphids in field, a 0 to 4 scale rating method was used. The response of each plant is as follows: a plant with scale 0 would have no aphids, 1 would have $\leq 10$ aphids, 2 would have $>10$ aphids but aphids scattered on the plant, 3 would have a dense colony (usually gathering 50 to several hundred aphids) on one leaf of the plant, and 4 would have high dense colonies on two or more leaves.

ChOICE ANd NO-CHOICE Tests. Cultivars 70096, Okeechobee, and Terrapin were further tested for their responses to BCB in the laboratory. Each cultivar was planted in four plastic pots ( 6 inches diameter by 6 inches deep) filled with soil, and four seeds were sown in each pot. The pots were fully watered and kept on a bench outside of a greenhouse under an automatic mist irrigation system that turns on for 5 min each day. At the five to eight leaf stage, the pots were moved into $18 \times$ $18 \times 24$-inch cages. Two cages were used for choice test with each cage containing one pot of each cultivar. For no-choice test, each of the two remaining pots for each cultivar was put into a cage. BCB adults used in the experiments were captured from the field with a net. Eight adults were released into a cage for the choice test while four adults were released into a cage for the no-choice test. All cages were kept in the insectarium at $80{ }^{\circ} \mathrm{F}$ with $14 \mathrm{~h}$ daylength. After $4 \mathrm{~d}$, the plants were scored for percent damage calculated as percent damage $=($ damaged leaves $/$ total leaves) $\times 100 \%$.

Statistical AnAlyses. Means and standard errors for BCB feedings and SL mines were computed for each 
date on which data were collected to monitor population dynamics of the insects. Percentage data were logtransformed before analysis of variance (ANOVA), but the reported values are in original units. ANOVA using the GLM procedure of SAS (version 9.2; SAS institute, Cary, NC) was performed on the data of BCB feedings, SL mines, and aphids scores among the romaine cultivars and among the iceberg cultivars, seperately. The least significant difference test (Steel and Torrie, 1980) was used for comparison of the differences of means among the cultivars at the $5 \%$ level of significance. Data on temperature from Oct. 2010 to Jan. 2011 at the Everglades Research and Education Center were obtained from the center's weather database (Everglades Research and Education Center, 2011).

\section{Results}

Air temperature AND LetTUCE GROWTH. During this growing season, air temperatures were normal in Oct. 2010, Nov. 2010, and Jan. 2011 in comparison with the averaged temperatures recorded between 1924 and 2001, while the averaged daily minimum and maximum temperatures in Dec. 2010 were 11 and $9^{\circ} \mathrm{F}$ lower than average (Table 1). There were $3 \mathrm{~d}$ with freezing temperatures in Dec. 2010 [7 Dec. $\left(29.9^{\circ} \mathrm{F}\right), 15$ Dec. $\left(26.2^{\circ} \mathrm{F}\right)$, and 28 Dec. $\left.\left(28.2^{\circ} \mathrm{F}\right)\right]$. Lettuce plants grew well during the early season, but the freezing temperatures caused damage to the lettuce and significantly delayed growth of the cultivars in late season. Because of the effect of low temperatures, it took $\approx 20 \mathrm{~d}$ or more for cultivars to mature.

Population Density Changes of INSECTS. BCB appeared in the field around 12 Nov. Foliar feeding by this insect increased from an average of one feeding incident per plant on 18 Nov. to 5.2 feeding incidents per plant on 9 Dec. for the cultivar Okeechobee (Fig. 1). Although direct counting of the number of insects was impractical because of their high mobility, field observations showed that the insect population peaked around $2 \mathrm{Dec}$. The freezing temperature on $7 \mathrm{Dec}$. totally eliminated $\mathrm{BCB}$, and there were no BCB observed in either site after that date. As a result, number of feeding incidents did not increase from 9 to 16 Dec. The BCB were seen again in the field in late Jan. 2011, but the

Table 1. Temperatures between Oct. 2010 and Jan. 2011 at the Everglades Research and Education Center, Belle Glade, FL.

\begin{tabular}{lcccccc}
\hline & & \multicolumn{2}{c}{ Avg for the mo..$^{\mathrm{y}}$} & & \multicolumn{2}{c}{ Avg (1924-2001) } \\
Month & Range $\left({ }^{\circ} \mathrm{F}\right)^{\mathrm{z}}$ & $\begin{array}{c}\text { Daily } \\
\min \left({ }^{\circ} \mathrm{F}\right)\end{array}$ & $\begin{array}{c}\text { Daily } \\
\max \left({ }^{\circ} \mathrm{F}\right)\end{array}$ & & $\begin{array}{c}\text { Daily } \\
\text { min }\left({ }^{\circ} \mathrm{F}\right)\end{array}$ & $\begin{array}{c}\text { Daily } \\
\max \left({ }^{\circ} \mathbf{F}\right)\end{array}$ \\
\hline Oct. 2010 & $54.3-92.1$ & 64.1 & 84.3 & & 65.6 & 85.0 \\
Nov. 2010 & $43.1-85.0$ & 57.3 & 79.3 & & 58.9 & 79.6 \\
Dec. 2010 & $26.2-78.6$ & 42.2 & 66.7 & & 53.5 & 75.8 \\
Jan. 2011 & $34.7-81.5$ & 50.4 & 73.0 & & 51.9 & 74.9 \\
\hline
\end{tabular}

${ }^{\mathrm{z}}\left({ }^{\circ} \mathrm{F}-32\right) \div 1.8={ }^{\circ} \mathrm{C}$.

${ }^{y} \mathrm{Min}=$ minimum, $\mathrm{Max}=$ maximum.

population density was not high and data were not collected.

Mines caused by SL larval tunneling through leaves were first observed in the field on 16 Nov. There was only one mine on 10 'Raleigh' plants with an average 0.1 mines per plant on 18 Nov. The SL mines increased to 3.0 per plant on 9 Dec. and had little change from 9 to 16 Dec. (Fig. 1), indicating that SL larvae were killed by the freezing temperature on $7 \mathrm{Dec}$.

Although population dynamics were not investigated in detail for aphids because of the difficulty in counting aphids in the field, this insect was noted to be present on lettuce from the beginning of Dec. 2010 to the end of the experiments. The population density was low in Dec. 2010 but high in Jan. 2011. Potato aphid was the predominant species of aphids as evidenced by their pink color, behavior of forming dense colonies, and body characteristics of long legs, antennae, and cornicles described in Nuessly and Webb (2010). Large numbers of aphids were found to stay together on the backsides of leaves of 'Okeechobee' and 'Terrapin' in Jan. 2011.

Cultivar responses. ANOVA showed significant differences for foliar feeding of BCB among the four romaine cultivars (Table 2). Cultivar 70096 had the least damage (an averaged $3.7 \%$ leaf damage) caused by BCB (Table 3). 'Manatee' had more leaf damage (12.1\%) than '70096' but significantly less damage than 'Okeechobee' (19.8\%) and 'Terrapin' (19.1\%). Leaf damage of three iceberg cultivars caused by BCB ranged from 16.3\% ('Raleigh') to $17.5 \%$ ('Gator') (Table $3)$, which were not significantly different (Table 2).

There were no significant differences detected for mean scores of mines created by SL larvae among the romaine cultivars (Tables 2-3). Likewise, the three iceberg cultivars responded

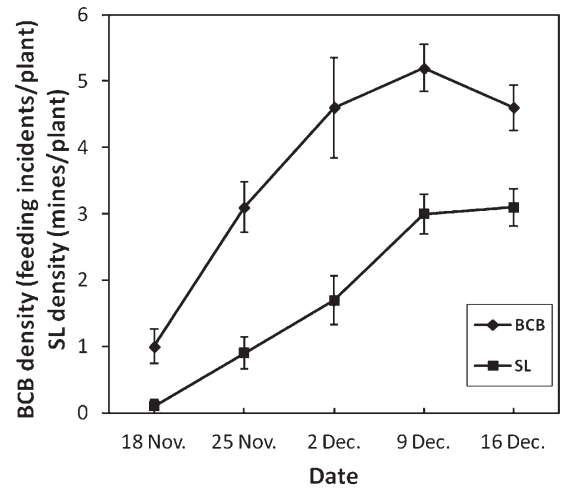

Fig. 1. Population density changes of banded cucumber beetle on susceptible romaine lettuce cultivar Okeechobee as evaluated by feeding incidents per plant and serpentine leafminer on susceptible iceberg lettuce cultivar Raleigh recorded as mines per plant. Cultivars were planted on 22 Oct. 2010 at Belle Glade, FL. Vertical bars are SE.

similarly to SL tunneling $(P=0.304)$ (Table 2).

For response to aphid infestation, highly significant differences were observed among the romaine cultivars $(P<0.001)$ and among the iceberg cultivars $(P<0.001)$ (Table 2$)$. 'Okeechobee' was the most susceptible romaine cultivar because the average reading of aphids on this cultivar was very high (3.7) indicating two or more dense colonies on most plants, whereas there were no dense colonies observed on 'Manatee', which had the lowest number of aphids (average reading 1.2) (Table 3). For iceberg cultivars, there were more aphids on 'Raleigh' than on the other two cultivars (Table $3)$, but there were no dense colonies seen on any of the iceberg cultivars suggesting that iceberg cultivars were less susceptible to potato aphids than romaine cultivars.

Choice AND NO-CHOICE TESTS. Table 4 presents the preliminary results of percent damaged leaves by $\mathrm{BCB}$. 
Table 2. Analysis of variance for feeding damage of banded cucumber beetle (BCB), tunneling damage of serpentine leafminer (SL), and aphids index in four romaine and three lettuce cultivars in separate field experiments at Belle Glade, FL.

\begin{tabular}{|c|c|c|c|c|c|c|c|c|c|c|}
\hline \multirow[b]{2}{*}{ Source of variation ${ }^{z}$} & \multirow[b]{2}{*}{ df } & \multicolumn{3}{|c|}{ BCB feeding ${ }^{y}$} & \multicolumn{3}{|c|}{ SL mines ${ }^{y}$} & \multicolumn{3}{|c|}{ Aphids ${ }^{y}$} \\
\hline & & MS & $F$ & $P$ & MS & $F$ & $P$ & MS & $F$ & $P$ \\
\hline \multicolumn{11}{|c|}{ Romaine lettuce ${ }^{x}$} \\
\hline Rep (Location) & 6 & 0.0007 & 0.11 & 0.994 & 0.0024 & 0.30 & 0.928 & 0.24 & 0.67 & 0.675 \\
\hline Cultivar & 3 & 1.0003 & 146 & $<0.001$ & 0.0020 & 0.25 & 0.861 & 91.68 & 259.6 & $<0.001$ \\
\hline Cultivar $\times$ location & 3 & 0.0028 & 0.41 & 0.747 & 0.0045 & 0.56 & 0.646 & 0.19 & 0.05 & 0.669 \\
\hline \multicolumn{11}{|c|}{ Iceberg lettuce } \\
\hline Location & 1 & 0.0004 & 0.21 & 0.652 & 0.0038 & 0.28 & 0.609 & 0.10 & 1.25 & 0.285 \\
\hline Rep (Location) & 6 & 0.0065 & 3.36 & 0.035 & 0.0132 & 0.97 & 0.485 & 0.29 & 3.45 & 0.032 \\
\hline Cultivar & 2 & 0.0029 & 1.50 & 0.262 & 0.0179 & 1.32 & 0.304 & 24.12 & 289.4 & $<0.001$ \\
\hline Cultivar $\times$ location & 2 & 0.0054 & 2.79 & 0.101 & 0.0038 & 0.28 & 0.764 & 0.22 & 2.60 & 0.115 \\
\hline
\end{tabular}

${ }^{\mathrm{z}}$ Rep $=$ replication.

'Data on BCB feeding and SL mines were collected on 16 Dec. 2010. Aphid readings were collected 20 Jan. 2011; MS = mean square.

${ }^{x}$ Statistical comparisons are within romaine and within iceberg cultivars only.

Table 3. Mean scores of banded cucumber beetle (BCB) feeding, serpentine leafminer (SL) tunneling, and aphids among four romaine and three iceberg lettuce cultivars in separate field experiments at Belle Glade, FL.

\begin{tabular}{llccc}
\hline Cultivar & \multicolumn{1}{c}{ Type } & $\begin{array}{c}\text { BCB }[\text { mean } \\
\pm \text { SE }(\%)]^{\mathrm{z}}\end{array}$ & $\begin{array}{c}\text { SL }[\text { mean } \\
\pm \text { SE }(\%)]^{\mathrm{z}}\end{array}$ & $\begin{array}{c}\text { Aphids }[\text { mean } \pm \text { SE } \\
(\mathbf{0}-4 \text { scale })]^{\mathrm{y}}\end{array}$ \\
\hline Okeechobee & Romaine & $19.8 \pm 0.52 \mathrm{a}^{\mathrm{w}}$ & $8.5 \pm 0.66$ & $3.7 \pm 0.32 \mathrm{a}$ \\
Terrapin & Romaine & $19.1 \pm 0.74 \mathrm{a}$ & $9.4 \pm 0.59$ & $3.1 \pm 0.58 \mathrm{~b}$ \\
70096 & Romaine & $3.7 \pm 0.29 \mathrm{c}$ & $9.2 \pm 0.56$ & $2.8 \pm 1.02 \mathrm{c}$ \\
Manatee & Romaine & $12.1 \pm 0.81 \mathrm{~b}$ & $8.7 \pm 0.31$ & $1.2 \pm 0.32 \mathrm{~d}$ \\
Gator & Iceberg & $17.5 \pm 0.84$ & $9.2 \pm 0.44$ & $0.9 \pm 0.05 \mathrm{~b}$ \\
8074 & Iceberg & $17.3 \pm 0.51$ & $10.0 \pm 1.04$ & $1.0 \pm 0.04 \mathrm{~b}$ \\
Raleigh & Iceberg & $16.9 \pm 1.05$ & $11.5 \pm 1.14$ & $1.8 \pm 0.04 \mathrm{a}$ \\
\hline
\end{tabular}

${ }^{2}$ Data on BCB feeding and SL mines were collected on 16 Dec. 2010.

y Aphid readings were collected $20 \mathrm{Jan} .2011 ; 0=$ (no aphids on the plant $), 1=(\leq 10$ aphids on the plant $), 2=(>10$ aphids, but aphids scattered on the plant), $3=$ (one dense colony on one leaf of the plant), $4=$ (dense colonies on two or more leaves of the plant).

${ }^{x}$ Statistical comparisons are within romaine and within iceberg cultivars only

"Means in the column followed by the same letter are not significantly different $(\alpha=0.05)$ using a least significant difference test (version 9.2; SAS Institute, Cary, NC).

Table 4. Preliminary results of percent damaged leaves caused by banded cucumber beetle in choice test and no-choice test conducted in an insectarium room.

\begin{tabular}{lccc}
\hline & \multicolumn{3}{c}{ Damaged leaves (\%) } \\
\cline { 2 - 4 } Test type & $\mathbf{7 0 0 9 6}$ & Okeechobee & Terrapin \\
\hline Choice test & 12 & 87 & 71 \\
No-choice test & 17 & 92 & 83 \\
\hline
\end{tabular}

${ }^{z}$ (damage leaves $\div$ total leaves $) \times 100 \%$.

The percentage of the damaged leaves for '70096' was consistently lower than 'Terrapin' or 'Okeechobee' in both choice and no-choice tests.

YIELD. The plants at site one with a planting date of 22 Oct. recovered from the December freezes and reached maturity. Ten heads of each plot from each replication were harvested to determine head weight per plant on 1
Feb. 2011. The plants at the other site recovered after the freezing damage but started bolting before their heads reached full size. No yield data were taken in that field. ANOVA revealed significant differences for yield in three iceberg cultivars, while there were no significant yield differences in the romaine cultivars (Table 5). 'Gator' and '8074' had significantly heavier heads than 'Raleigh'.

The plants in the experiments planted on 7 Oct. with insect control matured in early December and therefore the freezes did not affect the yield of the cultivars. Yield data collected on $8 \mathrm{Dec}$. were presented in Table 5. Among the romaine cultivars, three (Manatee, Terrapin, and Okeechobee) did not differ significantly from one another but yielded significantly higher than '70096'. 'Gator' was superior in yield to the other two iceberg cultivars.

Comparisons of the yield data obtained in different environments showed that the adverse environmental conditions of freezes and insect infestations reduced yield by $14 \%$ or more in romaine cultivar Manatee and all three iceberg cultivars (Table 5 ). 'Terrapin' and 'Okeechobee' yielded $3 \%$ and $6 \%$ lower when grown in the adverse environment. Interestingly yield of '70096' was $8 \%$ higher in the adverse environments than in the normal environments.

\section{Discussion}

In this growing season, $\mathrm{BCB}$ and SL began to be present in the middle of Nov. 2010 and built up their populations at slightly different paces (Fig. 1). However, because of the three freezes occurring in December, both BCB and SL were eliminated from the field, which did not allow us to investigate the whole population dynamics from the beginning to the end of the experiments. A small number of BCB were 
Table 5. Yield of the lettuce cultivars planted on 7 Oct. 2010 and harvested on 8 Dec. 2010 in the normal environments, and planted on 22 Oct. 2010 and harvested on 1 Feb. 2011 in the adverse environments (no insect control along with freezing damage) at Belle Glade, FL.

\begin{tabular}{llccr}
\hline & & \multicolumn{2}{c}{ Yield $(\mathrm{kg} / \mathrm{head})^{\mathrm{z}}$} & \\
\cline { 3 - 4 } Cultivar & Type & $\begin{array}{c}\text { Insect control } \\
(\text { mean } \pm \mathrm{SE})\end{array}$ & $\begin{array}{c}\text { No insects control } \\
\text { and freezing damage } \\
(\text { mean } \pm \text { SE) }\end{array}$ & $\begin{array}{c}\text { Adverse/ } \\
\text { normal (\%) }\end{array}$ \\
\hline Okeechobee & Romaine $\mathrm{y}^{\mathrm{y}}$ & $0.93 \pm 0.04 \mathrm{a}^{\mathrm{x}}$ & $0.87 \pm 0.03^{\mathrm{w}}$ & 94 \\
Terrapin & Romaine & $0.93 \pm 0.06 \mathrm{a}$ & $0.90 \pm 0.05$ & 97 \\
70096 & Romaine & $0.72 \pm 0.03 \mathrm{~b}$ & $0.78 \pm 0.03$ & 108 \\
Manatee & Romaine & $1.00 \pm 0.03 \mathrm{a}$ & $0.75 \pm 0.03$ & 75 \\
Gator & Iceberg & $0.83 \pm 0.05 \mathrm{a}$ & $0.64 \pm 0.03 \mathrm{a}$ & 77 \\
8074 & Iceberg & $0.66 \pm 0.03 \mathrm{~b}$ & $0.57 \pm 0.02 \mathrm{a}$ & 86 \\
Raleigh & Iceberg & $0.67 \pm 0.04 \mathrm{~b}$ & $0.42 \pm 0.03 \mathrm{~b}$ & 63 \\
\hline
\end{tabular}

${ }^{\mathrm{z}} \mathrm{l} \mathrm{kg}=2.2046 \mathrm{lb}$

y Statistical comparisons are within romaine and within iceberg cultivars only.

${ }^{x}$ Means in the column followed by the same letter are not significantly different $(\alpha=0.05)$ using a least significant difference test (version 9.2; SAS Institute, Cary, NC)

wYield data were collected from one location only.

noted late in the growing season but did not become economically important. In contrast, the aphid population was not disrupted by the freezing temperatures and was present from early December to end of the growing season. The population of aphids was low in Dec. 2010 but very high in Jan. 2011 as noted in susceptible cultivars such as 'Okeechobee' and 'Terrapin'. These results are in agreement with previous reports that $\mathrm{BCB}, \mathrm{SL}$, and aphids are the economically important insects causing significant damage to lettuce in the Everglades Agricultural Area in Florida (Nuessly and Nagata, 1994; Nuessly and Webb, 2010; Sethi et al., 2006).

The experimental approach used to study the responses of lettuce cultivars to infestation of $\mathrm{BCB}, \mathrm{SL}$, and aphids was a field experiment in conjunction with natural infestation similar to the experiment conducted in wheat (Sherman et al., 2010). One major advantage of conducting field experiments is that relatively more plant materials can be evaluated at one time. This feeding-choice test allowed insects to freely choose cultivars and plants to feed on and thus readily identified the susceptible cultivars. However, if a cultivar shows no sign of damage, it will be difficult to make a conclusion about whether the phenomenon is due to host plant resistance or other mechanism such as nonpreference. In this study, we did not observe a cultivar having no damage caused by $\mathrm{BCB}$, or SL, or aphids. The lowest rating was $3.7 \%$ leaf damage for cultivar 70096 in the $\mathrm{BCB}$ test (Table 3 ), suggesting that although this cultivar had the least leaf damage by $\mathrm{BCB}$, it was attacked by the insect. In the separate study conducted in an insectarium room, we found that '70096' consistently had less damage by BCB than 'Okeechobee' or 'Terrapin' in choice test and no-choice test (Table 4). Therefore, the damage differences detected among the cultivars in the field study should reflect the real responses of the cultivars to the infestation of $\mathrm{BCB}$. This finding could provide guideline for future research to screen numerous germplasm lines for resistance to different insect pests simultaneously in our breeding program.

Cultivars varied differently for responses to infestations of the three pests. Romaine cultivars 'Okeechobee' and 'Terrapin' were susceptible to BCB and aphids (Table 3 ). The average percentage of $\mathrm{BCB}$ feeding damage on '70096' was only 3.7, much lower than those of the remaining three romaine cultivars (Table 3 ). The same trend for '70096' was also observed in the choice and no-choice tests. These results suggest that '70096' is resistant to BCB. Several other studies showed that BCB could feed on senesced leaves but avoided feeding on young or middleaged leaves of the resistant cultivar Valmaine (Huang et al., 2002; Sethi et al., 2008). It will be interesting to know if '70096' has the similar resistance mechanism. 'Manatee' seems to be resistant to aphids because we found low numbers of aphids on this cultivar (Table 3). The three iceberg cultivars differed significantly only for the responses to aphid infestation with 'Raleigh' having more aphids (Table 3). Although tested in separate experiments, all romaine cultivars but 'Manatee' had dense colonies of aphids while there were no dense colonies on the iceberg cultivars indicating that the iceberg cultivars overall were less susceptible to aphids than romaine cultivars.

Yield responses of cultivars to adverse environmental conditions also varied. Four of seven cultivars had much lower yield in the adverse environment than in the normal environment ( $\mathrm{Ta}-$ ble 5 ). The remaining three cultivars (Okeechobee, Terrapin, and 70096) yielded similarly across the different environments, indicating these cultivars were more stable in yield than the other four cultivars. However, the different planting dates and other factors such as multiple insect species and different environmental factors in the present study made it difficult to evaluate influence of individual insect species on yield of each cultivar.

One of our objectives was to identify resistance in cultivars that can be used in IPM to control insects. BCB is a middle season insect of lettuce in southern Florida, and growers usually apply pesticides to the crop two times to control the insect. This study identified '70096' as a BCB resistant cultivar and showed that 'Manatee' also had less $\mathrm{BCB}$ damage than the susceptible cultivars. When '70096' is grown in the field, it would be reasonable not to spray any pesticides for BCB control, which can reduce production costs and protect the environment. If 'Manatee' is used as the cultivar for lettuce production, only one pesticide application may be needed. Since aphids, particularly the potato aphids, are present from the middle of the season through the end of the season, control of this insect is critical to lettuce industry. The three iceberg cultivars and romaine cultivar Manatee showed less infestation by aphids but still had various numbers of aphids on each plant. Although pesticide application to these cultivars may be needed as the market requires that lettuce heads or hearts should be free of insect contamination, application times of the pesticides could be reduced.

\section{Conclusions}

The experiments conducted in this study demonstrate that $\mathrm{BCB}, \mathrm{SL}$, and aphids are economically important insect pests on lettuce in southern Florida. BCB and SL start attacking plants earlier than aphids. Cultivars 
differed in their response to infestations of the insects. Romaine lettuce '70096' was resistant to $\mathrm{BCB}$ in the field experiment, and this was confirmed in nochoice test in laboratory. The iceberg cultivars were generally less susceptible to aphids than the romaine cultivars as no dense colonies were found on any of the iceberg cultivars. The cultivars with insect resistance such as '70096' can be useful as a component in a lettuce IPM program for protection of lettuce from damage caused by the insect pests.

\section{Literature cited}

Arend, A.J.M.V.D., A. Ester, and J.T.V. Schijndel. 1999. Developing an aphidresistant butterhead lettuce "Dynamite." EUCRPIA Leafy Vegetable '99, Palacky University, Olomouc, Czech Republic. p. 149-157.

Butrón, A., R.A. Malvar, P. Velasco, P. Revilla, and A. Ordás. 1998. Defense mechanisms of maize against pink stem borer. Crop Sci. 38:1159-1163.

Cardona, C., R. Gonzalez, and A.V. Schoonhoven. 1982. Evaluation of damage to common beans by larvae and adults of Diabrotica balteata and Cerotoma facialis. J. Econ. Entomol. 75:324-327.

Da Costa, C.P. and C.M. Jones. 1971. Resistance in cucumber, Cucumis sations L. to three species of cucumber beetles. HortScience 6:430-442.

Drees, B.M. and J. Jackman. 1999. Field guild to Texas insects. Gulf Publication, Houston, TX.

Everglades Research and Education Center. 2011. EREC Weather Station. 28 July 2011. <http://erec.ifas.ufl.edu/WD/ Ewdmain.htm>.

Guzman, V.L. 1986. Short Guzmaine, Tall Guzmaine and Floriglade, three cos lettuce cultivars resistant to lettuce mosaic virus. Inst. Food Agr. Sci., Univ. of Florida, Agr. Expt. Sta. Circ. S-326.
Guzman, V.L. and T.A. Zitter. 1983. Floricos 83: A cos lettuce cultivar resistant to two viruses, for Florida organic soils. Inst. Food Agr. Sci., Univ. of Florida, Agr. Expt. Sta. Circ. S-305.

Huang, J., G.S. Nuessly, H.J. McAuslane, and F. Slansky. 2002. Resistance to adult banded cucumber beetle (Coleoptera: Chrysomelidae) in romaine lettuce. J. Econ. Entomol. 95:849-855.

Layton, M.B., D.J. Boethel, and C.M. Smith. 1987. Resistance to adult bean leaf beetle and banded cucumber beetle (Coleoptera: Chrysomelidae) in soybean. J. Econ. Entomol. 80:151-155.

Liu, Y.-B. and J.D. McCreight. 2006. Responses of Nasonovia ribisnigri (Homoptera: Aphididae) to susceptible and resistant lettuce. J. Econ. Entomol. 99: 972-978.

McCreight, J.D. 2008. Potential sources of genetic resistance in lettuce to the lettuce aphid, Nasonovia ribisnigri (Mosely) (Homoptera: Aphididae). HortScience 43:1355-1358.

Nuessly, G. and R.T. Nagata. 1993. Evaluation of damage by serpentine leafminer and banded cucumber beetle to cos lettuce. Everglades Res. Edu. Ctr. Res. Rpt. EV-1993-2:76-77.

Nuessly, G. and R.T. Nagata. 1994. Differential probing response of serpentine leafminer, Liriomyza trifolii (Burgess), on Cos lettuce. J. Entomol. Sci. 29:330-338.

Nuessly, G. and S.E. Webb. 2010. Insect management for leafy vegetables. Univ. of Florida, Inst. Food Agr. Sci. Ext. ENY475 .

Palumbo, J., C. Mullis, Jr., F. Reyes, A. Amaya, L. Ledesma, and L. Cary. 2000. Population Dynamics and Distribution of Aphid Species on Head Lettuce in the Yuma Valley. 28 July 2011. <http://ag.arizona. edu/pubs/crops/azl177/azl177-lj.pdf>.

Reinink, K. and F.L. Dieleman. 1989. Comparison of sources of resistance to leaf aphids in lettuce (Lactuca sativa L.). Euphytica 40:21-29.
Reinink, K., F.L. Dieleman, J. Jansen, and A.M. Montenarie. 1989. Interactions between plant and aphid genotypes in resistance of lettuce to Myzus persicae and Macrosiphum euphorbiae. Euphytica 43: 215-222.

Saba, F. 1970. Host plant spectrum and temperature limitations of Diabrotica balteata. Can. Entomol. 102:684-691.

Schalk, J.M., A. Jones, and P.D. Dukes. 1986. Factors associated with resistance in recently developed sweet potato cultivars and germplasm to the banded cucumber beetle, Diabrotica balteata LeConte. J. Agr. Entomol. 3:329-334.

Sethi, A., H.J. McAuslane, H.T. Alborn, R.T. Nagata, and G.S. Nuessly. 2008. Romaine lettuce latex deters feeding of banded cucumber beetle: A vehicle for deployment of biochemical defenses. Entomol. Exp. Appl. 128:410-420.

Sethi, A., H.J. McAuslane, R.T. Nagata, and G.S. Nuessly. 2006. Host plant resistance in romaine lettuce affects feeding behavior and biology of Trichoplusia ni and Spodoptera exigua (Lepidoptera: Noctuidae). J. Econ. Entomol. 99:2156-2163.

Sherman, J.D., D.K. Weaver, M.L. Hofland, S.E. Sing, M. Buteler, S.P. Lanning, Y. Naruoka, F. Crutcher, N.K. Blake, J.M. Martin, P.E. Lamb, G.R. Carlson, and L.E. Talbert. 2010. Identification of novel QTL for sawfly resistance in wheat. Crop Sci. 50:73-86.

Smith, C.M. 1989. Plant resistance to insects: A fundamental approach. Wiley, New York.

Steel, R.G.D. and J.H. Torrie. 1980. Principals and procedures of statistics, 2nd ed. McGraw-Hill, New York.

U.S. Department of Agriculture. 2011. USDA Economics, Statistics, and Market Information System. 28 July 2011. <http:// usda.mannlib.cornell.edu/MannUsda/ viewDocumentInfo.do?documentID= 1576>. 